\title{
KUZEY KIBRIS TÜRK CUMHURIYETI'NDE (KKTC) SIĞIR, KOYUN VE KEÇİLERDE BAZI VİRAL ENFEKSIYYONLARIN ARAŞTIRILMASI
}

\begin{abstract}
Ibrahim BURGU
Seval BILGE

F. ALKAN

Kadir YEŞILBA $\breve{G}^{3}$

Investigation on some viral infections in cattle, sheep and goats in Turkish Republic of Northern Cyprus

Summary: As preliminary research, 264 blood sera samples obtained from cattle for IBR, BVD, EBL, 174 sheep blood sera samples for visna-maedi and 37 goats blood sera samples for CAE virus specific antibodies were examined. In order to detect the existence of some economically important diseases in sheep, cattle and goats of Turkish Republic of Northern Cyprus. We have not detected EBL antibodies in cattle, visna-maedi antibodies in sheep and CAEV antibodies in goats. But cattle blood sera were found to be positive at the ratio of $6.06 \%$ and $43.5 \%$ for IBR and BVD, respectively. These findings show that IBR and BVD virus infections are existing in the cattle of Turkish Republic of Northern Cyprus.

Key words: Cattle, goat, Turkish Republic of Northern Cyprus, sheep, viral infections ( $B L V, B V D, C A E V, I B R$, visna-maedi)

Özet: Bu araştırma KKTC'de yetiştirilen sığı, koyun ve keçilerde ekonomik yönden önemli viral enfeksiyonların varlığının araştırılması amacıyla bir ön çalışma olarak yapıldı. Bu amaçla 264 sı̆̆ır kan örneği IBR, BVD ve EBL, 174 koyun kan örneği visna-maedi ve 37 keçi kan örne ği caprine arthritis encephaliti.s viruslarına spesifik antikorlar yönünden kontrol edildi. Kontrol edilen sığırlarda $E B L$, koyunlarda visna-maedi ve keçilerde CAEV antikoru saptanmad. Ancak. sı̆̆ır kan serumlarının \%6.06'sı BHVI, \%43.5'i BVD antikorlarl yönünden pozitif bulundu. Bu ön falısmadan elde edilen veriler BHVI ve BVD virus enfeksiyonlarının KKTC sığır populasyonlarında varlı̆̆ını ortaya koydu.
\end{abstract}

Anahtar kelimeler: Keçi, KKTC, koyun, sı̆̆ır, viral enfeksiyonlar (BLV. $B V D, C A E V, I B R$, visna-maedi)

1. Prof.Dr., Ankara Üniversitesi Veteriner Fakültesi Viroloji Anabilim Dalı

2. Dr, Ankara Üniversitesi Veteriner Fakiultcsi Viroloji Anabilim Dalı

3. Araş.Gör.. Ankara Üniversitesi Veteriner Fakültesi Viroloji Anabilim Dalı 


\section{Giriş}

Sığırlarda yaygın olarak görülen enfeksiyöz bovine rhinotracheitis- enfeksiyöz pustular vulvovaginitis (IBR-IPV) enfeksiyonu, Herpesviridae familyasının alphaherpesvirinae alt grubunda klasifiye edilen bovine herpes virus 1 (BHV1) tarafından meydana getirilmektedir $(9,19)$. Virus daha çok solunum ve genital kanala lokalize olmakla birlikte konjuktivitis, enteritis, mastitis, abort, fötal sistemik enfeksiyonlar ile dermatitis ve tırnakarası bölgede lezyonlar da oluşturabilmektedir(20). Genç hayvanlarda üst solunum yolu enfeksiyonuna bağlı olarak görülen yemden yararlanma gücünün azalması ve ölümler, ergin hayvanlarda ağırlık kaybı, süt veriminde azalma, cmbriyonel ve fötal ölümler ile abortlar işletmelerde büyük ekonomik kayıplara neden olabilmektedir (17). Etkenin ganglion hücrelcrinde latent kalma özelliği nedeniyle mücadclenin zorluğu ve sürüde latent enfekte hayvanların varlı̆̆ı enfeksiyonun yaygınlığını artırmaktadır (1).

Sığırlarda sık olarak görülen bovine viral diarrhoea (BVD) enfeksiyonunda ise enterik semptomlarla seyreden akut hastalık tablosunun yanısıra, virusun intrauterin olarak fötusa geçmesi sonucunda konjenital enfeksiyonlar oluşmaktadır $(3,5)$. Özcllikle gebeliğin ilk $1 / 3$ lük döneminde oluşan intrauterin enfeksiyonlarda fötusun immun sistemi henüz gelişimini tamamlamadığı için fötus tarafından virusa karşı bir immun yanıt oluşturulamamaktadır(4). Gebelikte oluşan fötal enfeksiyonlarda mumifikasyon, abort, persiste enfekte veya konjenital anomalili buzağı doğumlan meydana gelmektedir. Sürüde persiste viremik hayvanların varlı̆gı enfeksiyonun yayılmasında önemli bir potansiyeldir. Bu nedenle eradikasyon çalışmalarında sürüdeki viremik hayvanların tespiti ile sürüden eliminasyonu gereklidir (6).

Ekonomik yönden kayılara neden olan enzootik sığır löykozu (EBL) lenf dügümlerinde tümör oluşumu, kan tablosu değişiklikleri ve lenfosit sayısının artışı ile karakterizedir. Enfeksiyonun en önemli bulaşma yolunun iatrojenik faktörler olduğu ortaya konulmuştur (7). Bunun yanısıra kastrasyon, boynuz kesme ve kulak numaralama gibi operatif uygulamalar, hastalann sekret (salya, burun akıntıs1, süt gibi) ve ekskretleri (idrar, gaita, gibi) ile sokucu sinekler önemli rol oynar (14, 15). Yapılan bir çalışmada (10) enfekte anneden doğan yavruların \%3-20 sinin EBL enfeksiyonu yönünden pozitif bulunduğu ve bunun kolostrum ve suit almalar sonucunda oluştugu bildirilmiştir. Etken sığırlara yerleştikten sonra yaşam boyu persiste olmasından dolayı, serolojik olarak pozitif tespit edilen hayvanlann sürüden eliminasyonu gerekmektedir.

Koyunlarda görülen visna-maedi (VM) ilc keçilerde görülen caprine arthritis encephalitis virus (CAEV) enfeksiyonlan, klinik ve patolojik bulguları yönünden farklı formlarda gözlenebilen ve inkubasyon sürelerinin uzun olması nedeniyle yavaş seyirli virus hastalıkları (slow virus infection) içinde yeralan viral enfeksiyonlardir. Bu enfeksiyonlar, enfekte hayvanlarda verim azalması, abortlar ve hastalığın ileri dönemlerinde meydana gelen öluimler nedeniyle önemli ekonomik kayıplar oluşturmaktadır $(2,16)$.

KKTC'de viral hastalıklanı araştırılması ve tespit edilen viral enfcksiyonlara ilgili kontrol programlarının uygulanması hedeflerine yönelik bir ön çalışma niteliğinde olan bu araştırmada, değişik zamanlarda sağlanan 264 adet sığır, 174 adet koyun ve 37 adet keçiye ait toplam 475 adet kan serum örneğinin sı ğrlarda IBR-IPV, BVD, EBL; koyunlarda VM ve keçilerde CAE virus spesifik antikorlan yönünden kontrol edilmesi ve böylece küçuik bir populasyona ait de olsa söz konusu viral enfeksiyonlara ilgili seroepidemiyolojik verilerin elde edilmesi amaçlanmıştır.

\section{Materyal ve Metot}

\section{Kan örnekleri}

KKTC Tarım Bakanlığı Veteriner Dairesi Müdürluigüune teşhis amacıyla getirilen 264 inek, 174 koyun ve 37 adet keçiye ait toplam 475 adet kan serumu örneği kullanıldı. 
ENFEKSIYONLARIN ARASTIRILMASI

\section{Viruslar}

Sı ̆̆ırlarda IBR-IPV antikorlarının tespitinde BHV1' in Colorado referens suşu (DKID50 $\left.=10^{-5.75} / 0.1 \mathrm{ml}\right)$, BVD-MD enfeksiyonunun teşhisinde BVDV'nin NADL referens suşu $\left(10^{-4.75} / 0.1 \mathrm{ml}\right)$ kullanıldı. EBL, visna-maedi ve CAE virus enfeksiyonlannın araştırılmasında ticari test kitlerinden yararlanıldı.

\section{Hücre kültürleri}

BHVI in titrasyonu ve mikronötralizasyon testi için Madin Darby Bovine Kidney (MDBK) huicre kültürü; BVDV'nin titrasyonu ve mikronötralizasyon testinde fötal dana böbrek (FDB) hücre kültürleri kullanıldı.

\section{Mikronötralizasyon testi}

BHVl ve BVDV antikorlannın tespiti amacıyla Frey ve Liess'in (12) bildirdiği yöntemden yararlanıldı. Şüpheli serumlar, BHV1 antikorlanının tespiti için sulandınlmadan, BVDV antikorlarının teşhisi için ise $1 / 5$ oranında sulandınlarak kullanıldı. Daha sonra her bir serum örneği mikronötralizasyon tablasının 2 gözüne $0.05 \mathrm{ml}$ miktannda konuldu. Serumlann iizerine enfeksiyözite güçleri tespit edilen viruslar 100DKID $_{50}$ oraninda sulandırılarak eşit hacimde ilave edildi. Daha sonra $\mathrm{CO}_{2}$ li etuivde BHV1 için 2 saat, BVDV için 1 saat inkubasyona bırakıldı. Süre sonunda tiim gözlere özel damlatıcılar yardımıyla 0.05 $\mathrm{ml}$ hücre süspansiyonu (300.000 hücre/ml) ilave edildi ve tabletler $37^{\circ} \mathrm{C}$ de inkubasyona bırakıldı. Sonuçlar, doku kültürü mikroskobunda sitopatolojik değişikliklcre göre degerlendirildi.

\section{AGID testi}

Sı ̆̆ırlarda EBLV antikorlarının tespitinde Frenzel ve Kaaden'in (11) bildirdikleri yöntem ile ticari test kitinden (Biochrom ); koyunlarda Visna-maedi virus ve keçilerde CAE virus antikorlarının tespitinde ise, Cutlip ve ark.(8) nın bildirdigi yöntem ile Weybridge Araştırma Enstitüsü -Ingiltere tarafından üretilen ticari test kitinden yararlanild.

Petri kutulannda hazırlanan yarı katı ortamda, özel delici ile merkezde bir ve bunun periferinde eşit uzaklıkta 6 delik açıldı. Merkezdeki deliğe konsantre antijen, periferdekilcre ise yöntemine uygun olarak test serumlan ile pozitif, ncgatif kontrol serumlan konuldu ve 72 saat nemli ortamda, oda isisinda inkubasyondan sonra sonuçlar çıplak göz. ile degerlendirildi.

\section{Bulgular}

\section{Mikronötralizasyon testi sonucu}

Kontrol edilen toplam 264 adet sığır kan serumu örneğinin 16 adedi (\%6.06) BHV1, 115 adedi (\%43.5) BVDV antikorlan yönünden pozitif bulundu.

\section{AGID testi sonucu}

Kontrol edilen kan serumları EBL, VM ve CAE virus antikorları yönünden negatif bulundu.

\section{Tartışma ve Sonuç}

Sığırlanı EBL, BVD ve IBR enfeksiyonları, enfekte hayvanlarda verim kayıpları ve ölümler nedeniyle önemli ekonomik kayıplara yol açmaktadır.

Bu çalışmada kontrol edilen toplam 264 adet sığır kan serum örneğinden \%6.06'sı (16/ 264) IBR antikoru, \%43.5'sı (115/264) BVD antikoru yönünden pozitif bulunmuştur.

Kıbris'da IBR-IPV virus enfeksiyonunun varlığı ilk olarak Gibbs ve ark (13) tarafından virus izolasyonuna dayanılarak bildirilmiştir.

BHV1 diğer herpesviruslarda olduğu gibi latent enfeksiyon oluşturma yeteneğindedir. Latent enfekte hayvanlar sürekli virus taşıyıcısı ve zaman zaman da virus saçıcısıdırlar. Bu hayvanların etkene spesifik antikor taşımaları virus taşıyıcısı ve saçıcısı olma özelliklerini ortadan 
kaldırmadığından IBR-IPV seropozitif hayvan, enfeksiyonun yayılmasında bir potansiycl olarak düşüinuilmelidir $(19,20)$. Bu nedenle IBR enfeksiyonunun uzun yıllar önce KKTC'de virolojik olarak tespit edildiği ve bu çalışmada saptanan seropozitiflik dikkate alınarak, enfeksiyonun yaygınlığının araştırılmasına yönelik olarak yapılacak daha geniş bir populasyonun örneklendiği yeni araştırmaların, enfeksiyonun durumuna ilgili daha gerçekçi verileri ortaya koyacağı düşünülmektedir.

BVD virus enfcksiyonu crişkin sığırlarda sindirim sistemi enfeksiyonuna neden olmaktadır. Erişkin gebe sığırların BVD virus ile enfeksiyonu sonucunda gelişen transplasental cnfeksiyonlar sonucunda ise abort, fötal mumifikasyon, cercbellar hipoplazi, oküler defektler vb. konjenital anomalili buzağı dogumlan ile pcrsiste viremik buzağı doğumlan oluşabilmektedir. Bu olgular hastalığa bağlı önemli ekonomik kayıplann temelini oluşturmaktadır (18).

Bu çalışmada elde edilen serolojik veriler KKTC'de sığır populasyonunda BVD virus enfeksiyonu varlığının oldukça yüksck düzeyde olduğunu ortaya koymuştur. Kontrol edilen kan serumu örneklerinde BVD virusa spesifik antikor oranı \% 43.5 olarak saptanmıştır. Bilindiği kadarıyla KKTC'de BVD virus enfcksiyonunun varlığına dair bir çalışma daha önce bildirilmemiştir. $\mathrm{Bu}$ nedenle bu verinin daha önce yapılan çalışmalar ile karşlaştırılabilmesi de mümkün olmamıştır.

Bu çalışmada sı̆̆ırların EBL, koyunların $\mathrm{VM}$ ve keçilerin CAE virus enfeksiyonuna ilgili antikor varlığı saptanmamıştır. Bununla beraber, örneklenen populasyonun çok sınırlı olduğu düşünüldügünde bu veriler söz konusu enfeksiyonların KKTC'de mevcut olup olmadığı hakkında tam bir fikir verememektedir.

Sonuç olarak, bu ön çalışmada KKTC'de IBR ve BVD virus enfeksiyonlarının varlığı ortaya konulmuş; ancak EBL, VM ve CAE enfcksiyonlarının durumu açıklık kazanmamıştır.
$\mathrm{Bu}$ nedenlc söz konusu enfeksiyonların varlığının araştırılması ve varlığı saptanan IBR ve BVD virus enfeksiyonlannın seroprevalansı, neden olduklan ekonomik kayıların boyutlarının hesaplanması ve gerekli göriilen kontrol programlarının belirlenebilmesi için daha geniş bir populasyonun örncklendiği araştırmalar yapılması önerilmektedir.

\section{Kaynaklar}

1. Ackermann M, Wyler $\mathbf{R}$ (1984) The DNA of an IPV strain of bovine herpesvirus-I in sacral sanglia during latency after intravaginal infection. Vet Microbiol, 9, 53-63.

2. Adams DS, Oliver RE, Ameghimo E, De Martin JC, Werwoerd DW, Honwers DJ, Waghela S, Garham JR, Hyllseth B, Dawson M, Trigo FJ, Mc Guire TC (1984) Global survey of serological evidence of caprine arthritis - encephalitis virus infection. Vet Rec, 115, 493-495.

3. Alkan F, Burgu I (1993) Investigation on the incidence of bovine viral diarrhoea virus in calves in Turkey. Dtsch Tierarztl Wschr, 100, 107-109.

4. Baker JC (1987) Bovine diarrhoea virus: A review. JAVMA, 190, 1450-1458.

5. Burgu I, Alkan F, Yeşilbağ K (1999) Türkive'de stğılarda persiste BVD virus enfeksiyonu. Ankara Üniv Vet Fak Derg, 46, 169-177.

6. Burgu í, Özkul A (1993) Detection by cullural iso)lation of bovine virus diarrhoea (BVD) virus following field infections in cattle and their fetuses in Turkey: Dtsch Tierarztl Wschr, 100, 361-363.

7. Bürki FA, Möstl K, Kasper A, Howardth E, Kunte CH (1983): Virologisch-serologische feststellung der enzootischen Rinder-leukose in Österreich und ihre gezielte freiwilige sanierung durch periodische Ermittlung und keulung von Seroreagenten Wicn $\mathrm{Ti}_{\text {- }}$ erarztl Mschr, 70, 1-4.

8. Cutlip RC, Jackson TA, Laird GA (1977) lmmunodiffusion test for ovine progressive pheumonia. Am J Vct Res, 38, $1081-1084$.

9. Fenner F (1987) Herpesviruses: Veterinary Virolog!: Academic Press, London, pp. 339-373.

10. Ferrer JF, Piper CE (1981) Role of colostrum and milk in the natural transmission of bovine leukemia virus. Cancer Res, 41, 4906-49(19.

11. Frenzel B, Kaaden OR (1980) Zur Standardizerung' der serologischen Diagnose der RinderleukrsseFortscritte der Veterinarmedizin. Herd, 30, 13 Kongressbericht, 188-189, vcrl.Paul Parey. Berlin und Hamburg.

12. Frey HR, Liess B (1971) Vermehrung.skinelik und verwendbarkeit eines stark zytopatogenen VD.MD vi. russtammes für diagnostische untersuchungen mit der mikrotiter-methode. Zbl Vet Med B, 18, 61-71. 


\section{ENFEKSIYONLARIN ARAŞTIRILMASI}

13. Gibbs EPJ, Pitzolis G, Lawman MJP (1975) Use of corticosteroids to isolate IBR virus from cattle in Cyprus after respiratory disease and ataxia. Vet Rec, 95, 464-466.

14. Kaaden OR. (1980) Aktuelle Fragen der Rinderleukose Forschung and Bekampfung. Dtsch Ticrarztl Wschr, 87. $411-43$.

15. Miller, J.M., van der Maaten, M.J. (1982): Bovine leukosis-its importance to the dain industry in the United States. J Dairy Sci, 65, 2194-2203.

16. Paisson PA (1979) Maedi and Visna in Sheep. In: Slow Viruses of Animals and Man RH Kimberlin (Ed): North-Holland Publishing Company.Amsterdam, pp. 17-43.

17. Pierson RH, Vair CA (1965) The economic loss associaled with infectious hovine rhinotracheitis in a dairy herd. JA VMA, 147, 35()-352.
18. Rhocder PL, Jeffrey M, Cranwell MP (1986) Pestivirus foetopathogenicity in cattle: Changing equel with fetal maturation. Vet Rec, 114, 44-48.

19. Straub OC (1990) Infectious Bovine Rhinotracheitis. In: $B$ Dinter and B Morein. (Ed.): Virus Infections of Ruminants. Elsevier of Publishers, Amsterdam. pp. $71-108$.

20. Straub OC (1991) BHVI Infections: Relevance and spread in Europe. Comp Immunol Microbiol Infec Dis, 14, 175-186.

\section{Yazışma Adresi}

Prof.Dr.Ibrahim BURGU

Ankara Üniversitesi Veteriner Fakültesi

Viroloji Anabilim Dali

Dtskapt/Ankara 